\title{
PEMETAAN SOSIAL (SOCIAL MAPPING) MASYARAKAT DALAM UPAYA MENDUKUNG PENGEMBANGAN USAHATANI POLIKULTUR PERKEBUNAN TERINTEGRASI (UTPPT)
}

\section{SOCIAL MAPING COMMUNITY EFFORTS TO SUPPORT THE DEVELOPMENT OF INTEGRATED PLANTATION FARMING POLYCULTURE (UTPPT)}

\author{
Rina Nuryati ${ }^{* 1}$, Lies Sulistyowati ${ }^{2}$, Iwan Setiawan ${ }^{3}$, Trisna Insan Noor $^{4}$ \\ ${ }^{1}$ Dosen Fakultas Pertanian, Universitas Siliwangi, Tasikmalaya. \\ ${ }^{2,3,4}$ Dosen Fakultas Pertanian dan Sekolah Pasca Sarjana, Universitas Padjajaran, Sumedang. \\ *Email Corresponding: rinanuryati@unsil.ac.id
}

\begin{abstract}
ABSTRAK
Pemda melalui kewenangan yang dimilikinya, dituntut untuk mengelola sumberdaya secara efektif dan efisien. Penelitian ini dilakukan untuk memperoleh gambaran mengenai kondisi social masyarakat lokal melalui pemetaan social dengan pendekatan yang memungkinkan masyarakat desa saling berbagi, meningkatkan dan menganalisis pengetahuan mereka tentang kondisi dan kehidupan desa serta membuat rencana dan tindakan nyata untuk memungkinkan praktisi pembangunan, pejabat pemerintah dan masyarakat setempat bekerjasama merencanakan konteks program yang tepat. Penelitian ini merupakan penelitian deskriptif dilaksanakan dari Februari-Agustus 2018. Metode penelitian adalah survey dengan Participatory Rural Appraisal (PRA). Hasil penelitian bahwa UTPPT merupakan usahatani yang telah lama ditekuni petani dan telah menjadi matapencaharian pokok sebagian besar penduduk. Kondisi lahan termasuk kategori subur dan sangat subur ditunjang keberadaan berbagai kelembagaan formal maupun non formal serta telah terdapat alur sistem input dan output yang berjalan optimal ditunjang pemasaran produk hasil pertanian yang telah berjalan lancar sehingga mendukung pengembangan UTPPT. Terdapat beberapa hal yang memerlukan penanganan lebih lanjut diantaranya kondisi iklim tidak menentu, kekeringan di MK dan banjir serta longsor di $\mathrm{MH}$, serangan hama dan penyakit yang meningkat pada $\mathrm{MH}$, kondisi kebun yang belum terpelihara dan masih menggunakan bibit local, peran kelembagaan belum optimal, masih banyak produk yang dijual dalam bentuk mentah sehingga harga produk murah.
\end{abstract}

Kata kunci: UTPPT, Pemetaan social, PRA, alur sistem input output.

\section{ABSTRACT}

Local governments through their authority, are required to manage resources effectively and efficiently. This research was conducted to obtain a picture of the social conditions of local communities through social mapping with an approach that allows villagers to share, improve and analyze their knowledge of village conditions and life and make plans and concrete actions that enable development practitioners, government officials and local communities to work together plan the appropriate program context. This research is a descriptive study carried out from February-August 2018. The research method is a survey with Participatory Rural Appraisal (PRA). The results of the study show that UTPPT is a farm that has long been occupied by farmers and has become the main livelihood of the majority of the population. Land conditions including fertile and very fertile categories are supported by the existence of a variety of formal and informal institutions and there has been an optimal flow of input and output systems that are supported by the marketing of agricultural products that have been running smoothly so as to support the development of UTPPT. There are several things that need further handling including uncertain climate conditions, drought in the Constitutional Court and floods and landslides in $\mathrm{MH}$, increased pest and disease attacks on $\mathrm{MH}$, conditions 
PEMETAAN SOSIAL (SOCIAL MAPPING) MASYARAKAT DALAM UPAYA MENDUKUNG

PENGEMBANGAN USAHATANI POLIKULTUR PERKEBUNAN TERINTEGRASI (UTPPT)

Rina Nuryati, Lies Sulistyowati, Iwan Setiawan, Trisna Insan Noor

of gardens that have not been maintained and are still using local seeds, the role of institutions is not optimal, still many products are sold in raw form so the price of the product is cheap.

Keywords: UTPPT, social mapping, PRA, input output system flow.

\section{PENDAHULUAN}

Era desentralisasi telah membuka peluang Pemerintah Daerah (Pemda) termasuk Kabupaten Tasikmalaya untuk mengelola masalah yang ada pada wilayahnya secara mandiri, dari mulai proses formulasi, implementasi dan evaluasi kebijakan serta program pembangunan yang sesuai dengan kebutuhan masyarakat setempat. Pemda Kabupaten Tasikmalaya dalam menjalankan kewenangannya tersebut diharapkan mampu mengelola sumbersumber daya yang tersedia secara efektif dan efisien.

Sebelum melakukan proses formulasi dan mengimplementasikan serta mengevaluasi kebijakan dan program pembangunan tersebut, terlebih dahulu perlu dilakukan pemetaan sosial (Sosial Mapping). Pambudi Handoyo dan Arief Sudrajat (2016) menyatakan pemetaan sosial merupakan kegiatan yang sangat penting untuk dilaksanakan guna memahami kondisi sosial masyarakat lokal, karena setiap masyarakat memiliki kondisi social yang berbeda yang dapat mengakibatkan masyarakat mempunyai masalah dan kebutuhan yang berbeda pula. Pemetaan social di samping dapat mengetahui kebutuhan dasar masyarakat, potensi sumberdaya dan modal social masayarakat, juga dilakukan untuk mengenal stakeholder dalam hubungannya dengan keberadaan dan aktivitas pelaku dalam program, mengidentifikasi permasalahan yang dirasakan komuniti dalam meningkatkan kesejahteraan hidupnya dan menganalisis potensi konflik yang ada pada masyarakat.

Bahrudin, et., al., 2013 menyatakan pemetaan sosial dapat memberikan gambaran menyeluruh dari lokasi yang dipetakan, yang meliputi aktor yang berperan dalam proses relasi sosial, jaringan sosial, kekuatan dan kepentingan masing-masing aktor dalam kehidupan masyarakat terutama dalam peningkatan kondisi kehidupan masyarakat, masalah sosial yang ada termasuk keberadaan kelompok rentan, serta potensi yang tersedia, baik alam, manusia, finansial, dan infrastruktur maupun modal sosial

Hal tersebut berkaitan dengan strategi pengembangan pertanian yang harus mengakomodasi heterogenitas yang ada dalam aspek biofisik, ekonomi, sosial budaya, kelembagaan dan lingkungan (Notenbaert, et., al. 2013). Kabupaten Tasikmalaya merupakan daerah yang memiliki persebaran lahan kritis yang mencapai 12.040 ha. Lahan kritis tersebut berdasarkan kepemilikannya seluas 9.400 ha dimiliki masyarakat dan hanya seluas 2.640 ha dikuasai pemerintah (Distanhut, 


\section{JURNAL AGRISTAN}

Volume 2, Nomor 1, Mei 2020

2005). Selain itu Kabupaten Tasikmalaya termasuk daerah rawan bencana di wilayah Jawa Barat, khususnya tanah longsor (pergerakan tanah). BPBD Provinsi Jawa Barat menjelaskan Kabupaten Tasikmalaya termasuk kabupaten yang menempati urutan kedua di Jawa Barat yang sering mengalami longsor. Sepanjang tahun 2016 (Januari November 2016) telah terjadi 1.074 kejadian bencana alam yang terdiri dari 227 kebakaran, 206 banjir, 439 kali tanah longsor, 164 putting beliung dan 38 gempa bumi.

Dalam keadaan ini perlu diterapkan sistem pengelolaan tanah dan air secara terpadu dan tepat agar sistem pertanian dapat berproduksi secara berkelanjutan. Abdurahman, et., al. (1997) pola pengembangan pertanian yang sesuai adalah pola usahatani campuran secara terpadu. Pasandaran, et.al. (2005), usahatani terintegrasi merupakan sistem pertanian yang dicirikan dengan keterkaitan yang erat antara komponen tanaman dan ternak dalam suatu wilayah atau suatu usahatani. Integrasi tanaman dan ternak menurut Liyama, et. al. (2007) dapat dipandang sebagai solusi yang secara ekonomi layak diusahakan sekaligus ramah lingkungan untuk meningkatkan taraf hidup petani dalam mewujudkan sistem pertanian yang berkelanjutan.

Pelaksanaan Usahatani integrasi tanaman dan ternak/UTPPT memerlukan kajian yang lengkap, diantaranya adalah aspek sosial ekonomi masyarakat yang mendukung keberlanjutan usahatani tersebut di lapangan. Sehubungan dengan hal tersebut maka dilakukan kajian pemetaan sosial guna memperoleh gambaran menyeluruh dari lokasi yang dipetakan. Tujuan penelitian ini adalah untuk melakukan pendekatan yang memungkinkan masyarakat desa untuk saling berbagi, meningkatkan dan menganalisis pengetahuan mereka tentang kondisi dan kehidupan desa serta membuat rencana dan tindakan nyata termasuk untuk memungkinkan praktisi pembangunan, pejabat pemerintah dan masyarakat setempat untuk bekerjasama untuk merencanakan konteks program yang tepat.

\section{METODE PENELITIAN}

Penelitian yang dilakukan merupakan penelitian deskriptif yaitu penelitian yang mendeskripsikan data pemetaan social ekonomi masyarakat Kabupaten Tasikmalaya untuk pengembangan UTPPT. Penelitian dilaksanakan secara mendalam di Desa Setiawaras Kecamatan Cibalong Kabupaten Tasikmalaya dari bulan Februari sampai Agustus 2018. Metode penelitian yang digunakan adalah metode Survey dengan menggunakan analisis Participatory Rural Appraisal (PRA).

PRA merupakan pendekatan memungkinkan masyarakat secara bersama-sama menganalisis masalah kehidupan dalam upaya merumuskan 
PEMETAAN SOSIAL (SOCIAL MAPPING) MASYARAKAT DALAM UPAYA MENDUKUNG

PENGEMBANGAN USAHATANI POLIKULTUR PERKEBUNAN TERINTEGRASI (UTPPT)

Rina Nuryati, Lies Sulistyowati, Iwan Setiawan, Trisna Insan Noor

perencanaan dan kebijakan secara nyata atau merupakan suatu metode untuk memahami suatu desa secara partisipatif dalam hal permasalahan dan upaya antisipasi yang dibutuhkan dengan mendasarkan pada potensi dan kendala sumberdaya yang tersedia. Dalam pelaksanaannya PRA ditekankan pada keterlibatan masyarakat (partisipasi) dalam keseluruhan kegiatan, peningkatan kemandiri dan kekuatan internal.

Data yang ditelaah pada penelitian ini meliputi : sejarah desa, bagan kecenderungan perubahan, kalender musim, penelusuran desa/transek, sketsa area usaha, pemetaan hubungan masyarakat dengan kelembagaan, kajian mata pencaharian, dan arus masukan dan keluaran.

\section{HASIL DAN PEMBAHASAN}

\subsection{Kondisi umum wilayah penelitian}

Desa Setiawaras merupakan salah satu desa yang berada di Kecamatan Cibalong Kabupaten Tasikmalaya di samping desa Parung, Eureunpalay, Cisempur dan Cibalong. Desa Setiawaras memiliki luas area terluas dari seluruh desa yang ada di Kecamatan Cibalong yaitu mencapai 1.829 ha atau sekitar 31 persen dari luas total kecamatan Cibalong dengan rata-rata ketinggian tempat $400 \mathrm{~m} \mathrm{dpl}$. Jumlah penduduk sebanyak 4.134 orang berjenis kelamin laki-laki dan 4.039 orang berjenis kelamin perempuan, sehingga jumlah total penduduknya mencapai 8.173 orang dengan sex ratio 102. Kepadatan penduduk mencapai 447 orang per $\mathrm{km}^{2}$ dengan rata-rata penduduk per keluarga 3,0 orang (Profil Desa Kecamatan Cibalong Tahun 2015).

\subsection{Pemetaan Sosial Ekonomi}

Pemetaan sosial (sosial mapping) merupakan proses penggambaran masyarakat yang sistematik serta melibatkan pengumpulan data dan informasi mengenai masyarakat termasuk di dalamnya profile dan masalah sosial yang ada pada masyarakat yang bersangkutan. Netting, Kettner dan McMurtry (1993) menjelaskan pemetaan sosial disebut juga dengan sosial profiling atau pembuatan profile suatu masyarakat, yang bermanfaat untuk membantu dan memahami perubahan-perubahan dalam masyarakat

Penelusuran sejarah desa diperlukan untuk mengungkap kembali sejarah masyarakat dan hal-hal lainnya yang terkait dengan Desa. Berdasarkan hasil penelusuran sejarah desa diketahui berbagai perubahan yang dialami dalam masyarakat terutama yang terkait dengan pengembangan UTPPT diantaranya adalah aktivitas budidaya tanaman merupakan aktivitas yang sudah lama ditekuni oleh masyarakat yaitu sekitar tahun 1920 walaupun keberadaan kelembagaan pendukungnya yaitu Balai Penyuluhan Pertanian baru dibentuk pada tahun 1990 dan aktivitas penyuluhan mulai terselenggara pada tahun 1995. 
JURNAL AGRISTAN

Volume 2, Nomor 1, Mei 2020

Aktivitas usahatani sempat diselenggarakan oleh BPP semakin terganggu dengan meletusnya Gunung intensif diikuti dengan kegiatan penyuluhan Galunggung pada tahun 1982 yang yang juga dilaksanakan semakin intensif menyebabkan banyak petani mengalami pada tahun 2005.

kerugian. Pada tahun 2000 kegiatan yang

Tabel 1. Sejarah Desa Dan Masa Kepemimpinanya.

\begin{tabular}{|c|c|}
\hline Tahun & Kejadian \\
\hline 1900 & $\begin{array}{l}\text { Desa setiawaras asalnya desa Sumbawa dengan kades Bapak Naria } \\
\text { Dikarta }\end{array}$ \\
\hline 1918 & Kepala desa Sumbawa diganti oleh Bapak Sastra Dimaja \\
\hline 1920 & Mulai mengenal tanaman dan budidayanya \\
\hline 1923 & $\begin{array}{l}\text { Kepala desa bapak Wijatma Dipura, dimekarkan jadi } 7 \text { desa : Sumbawa, } \\
\text { Cisempur, Batulawang, Cinunjang, Babakan Kupa, Cibengan / Cikadondong } \\
\text { dan Bojong asih }\end{array}$ \\
\hline 1934-1938 & Desa Batulawang dengan kades Bapak Nata Diharja \\
\hline 1939-1946 & $\begin{array}{l}\text { Desa batulawang diganti nama dengan Desa Setiawaras, kades Bapak } \\
\text { Juarsa }\end{array}$ \\
\hline $1946-1947$ & $\begin{array}{l}\text { Desa setiawaras dimekarkan menjadi Desa Setiawaras dan Cisempur } \\
\text { dengan kades Bapak Wiraatmaja }\end{array}$ \\
\hline $1952-1953$ & $\begin{array}{l}\text { Desa Setiwaras dan Cisempur digabung kembali menjadi Desa Setiawaras } \\
\text { dengan kades Bapak Odo Ssuanda }\end{array}$ \\
\hline 1953-1967 & Desa Setiawaras kades bapak Natadiria \\
\hline 1967-1976 & Kepala Desa Setiawaras bapak Odjo Sudarjo \\
\hline 1975 & Pembangunan sekolah \\
\hline 1976 & Desa Setiawaras dimekarkan menjadi : Setiawaras, Cisempur, Eureunpalay \\
\hline 1977-1978 & Pejabat bapak Encon Suryadikarta \\
\hline 1982 & Bencana alam : Gunung Galunggung meletus \\
\hline 1990 & Dibentuk BPP \\
\hline 1995 & Masuknya sistem penyuluhan pertanian \\
\hline 1978-1998 & Kades bapak Didi Rosidi \\
\hline 2000 & Kegiatan BPP mulai intens \\
\hline $1998-2005$ & Kades Setiawaras bapak Dahili \\
\hline 2005 & Kegiatan penyuluhan mulai intensif \\
\hline 2006 & Dibentuknya kelompok tani \\
\hline $2006-2007$ & Pejabat sementara bapak Iwan Kartiwa \\
\hline 2009 & Program PNPM pembangunan jalan \\
\hline 2009 & Gempa bumi $7,8 \mathrm{sr}$ \\
\hline 2011 & Dibentuknya Gapoktan \\
\hline 2015 & Dibentuknya KWT \\
\hline $2007-2012$ & Kades Dadi Kresnandi S.E \\
\hline $2012-2018$ & Kades bapak Didih Iskandar \\
\hline
\end{tabular}

Sumber : Pak Asep (Aparat Desa) dan RPJMD Setiawaras

\section{Kelompok tani di Desa Setiawaras} mulai dibentuk pada tahun 2006 dan saat ini telah terdapat 13 kelompok tani yang tersebar di setiap kedusunan. Pada tahun 2009 dilakukan pembangunan jalan berkenaan dengan dilaksanakannya program PNPM yang ditujukan untuk pembangunan jalan sehingga membantu meningkatkan mobilitas petani karena jalan usahatani menjadi lebih baik. Pembentukan Gapoktan dimulai pada tahun 2011 untuk mewadahi kelompok tani termasuk pembentukan Kelompok Wanita Tani (KWT) pada tahun 2015 yang 
PEMETAAN SOSIAL (SOCIAL MAPPING) MASYARAKAT DALAM UPAYA MENDUKUNG PENGEMBANGAN USAHATANI POLIKULTUR PERKEBUNAN TERINTEGRASI (UTPPT)

Rina Nuryati, Lies Sulistyowati, Iwan Setiawan, Trisna Insan Noor

semakin menunjukkan peranan sektor pertanian dalam menunjang aktivitas kehidupan masyarakat di Desa Setiawaras.

Bagan kecenderungan perubahan merupakan teknik yang menggambarkan perubahan-perubahan yang terjadi berbagai keadaan (baik perubahan dari dalam desa maupun dari luar desa), kejadian serta kegiatan masyarakat dari waktu ke waktu. Kecenderungan perubahan dan perkembangan tataguna lahan di Desa Setiawaras (Tabel 2) memperlihatkan komoditas tanaman pangan berupa padi pada ketiga periode pengamatan (Tahun 1990-1999, 20002009, 2010-2018) menunjukkan kecenderungan semakin meningkat. Tanaman padi diusahakan petani umumnya ditujukan untuk memenuhi kebutuhan keluarga petani, apabila kebutuhan telah terpenuhi kelebihan hasil produksi padi akan dijual oleh petani.

Tabel 2. Bagan Kecenderungan Perubahan

\begin{tabular}{|c|c|c|c|c|}
\hline \multirow[t]{2}{*}{ No. } & \multirow[t]{2}{*}{ Komoditas } & \multicolumn{3}{|c|}{ Waktu Perubahan } \\
\hline & & $1990-1999$ & $2000-2009$ & $2010-2018$ \\
\hline & Pangan & & & \\
\hline \multirow[t]{2}{*}{1} & Padi & 000 & 0000 & 00000 \\
\hline & Hortikultura & & & \\
\hline \multirow[t]{2}{*}{2} & Pisang & 000 & 0000 & 00000 \\
\hline & Perkebunan & & & \\
\hline 3 & Kelapa & 000 & 0000 & 00000 \\
\hline 4 & Kakao & 000 & 0000 & 00000 \\
\hline 5 & Kapulaga & 000 & 0000 & 00000 \\
\hline 6 & Pala & 000 & 0000 & 00000 \\
\hline 7 & Lada & 000 & 0000 & 00000 \\
\hline 8 & Vanili & 000 & 0 & \\
\hline 9 & Cengkeh & 000 & 000 & OO \\
\hline \multirow[t]{2}{*}{10} & Gula Aren & 000 & 00 & 0 \\
\hline & Tanaman Kayu & & & \\
\hline \multirow[t]{2}{*}{11} & Albasiah & 000 & 0000 & 00000 \\
\hline & Peternakan & & & \\
\hline 12 & Sapi & 000 & 0000 & 00 \\
\hline 13 & Kambing & 000 & 0000 & 00000 \\
\hline 14 & Domba & 000 & 0000 & 00000 \\
\hline 15 & Ayam Pedaging & 000 & 000 & 00000 \\
\hline 16 & Ayam Petelur & 000 & 000 & 00000 \\
\hline \multirow[t]{2}{*}{17} & Burung Puyuh & 0 & OO & 0000 \\
\hline & Perikanan : & & & \\
\hline \multirow[t]{2}{*}{18} & Ternak ikan (lele, nila, mas, dll) & 000 & 000 & 0000 \\
\hline & Industri : & & & \\
\hline 19 & $\begin{array}{l}\text { Industri Kecil (Home Industri olahan } \\
\text { makanan) }\end{array}$ & 0 & 000 & 00000 \\
\hline \multirow[t]{2}{*}{20} & Industri Menengah (Pabrik sumpit) & 0 & 000 & 00000 \\
\hline & Lainnya : & & & \\
\hline 21 & Luas Lahan Perkebunan & 000 & 0000 & 00000 \\
\hline 22 & Luas Lahan Sawah & 00000 & 000 & 00 \\
\hline 23 & Bangunan (rumah, instansi, dll) & 000 & 0000 & 00000 \\
\hline 24 & Pendapatan & 000 & 000 & 00000 \\
\hline
\end{tabular}

Keterangan : $\quad$ o: Keberadaan sangat sedikit ; 00000 : Keberadaan sangat banyak 
Hasil produksi tanaman hortikultura berupa pisang menunjukkan kecenderungan perubahan yang semakin meningkat, demikian juga dengan komoditas tanaman perkebunan baik kelapa, kakao, kapulaga, pala dan lada. Akan tetapi tanaman perkebunan berupa vanili, cengkeh dan aren memperlihatkan kecenderungan perubahan yang semakin menurun bahkan vanili pada periode pengamatan tahun pertama menjadi tidak ada lagi pada periode pengamatan tahun ketiga. Pengusahaan tanaman perkebunan berupa kelapa, kakao, kapulaga, lada dan pala memperlihatkan kecenderungan mengalami peningkatan disebabkan oleh semakin meningkatnya keinginan petani untuk mendapatkan sumber pendapatan dari kegiatan usahataninya pada keterbatasan lahan yang ada. Penurunan pengusahaan tanaman vanili menjadi tidak lagi diusahakan petani, menurut petani karena tanaman vanili merupakan tanaman yang memerlukan pemeliharaan khusus (diantaranya : proses penyerbukan harus senantiasa dibantu oleh petani) sehingga cukup merepotkan dan pada akhirnya tidak menarik lagi bagi petani untuk mengusahakannya. Mochtar (2012) menjelaskan bahwa bunga vanili tidak mampu melakukan penyerbukan sendiri karena kepala putik tertutup oleh lamella bunga secara keseluruhan, sehingga penyerbukannya harus dibantu.
Tanaman kayu berupa albasiah memperlihatkan kecenderungan perubahan semakin meningkat karena tanaman kayu albasiah merupakan tanaman kayu yang umur produksinya lebih pendek dibandingkan dengan tanaman kayu mahoni dan jati sehingga bisa dijadikan sebagai sumber tabungan bagi keluarga petani yang dapat digunakan petani menutupi kebutuhan keluarga apabila ada keperluan keluarga yang cukup besar (misal : biaya sekolah, hajatan, dII).

$$
\text { Pengusahaan ternak sapi }
$$
memperlihatkan kecenderungan semakin menurun, akan tetapi pengusahaan ternak kambing, domba, ayam pedaging dan ayam petelur serta burung puyuh memperlihatkan kecenderungan perubahan yang semakin meningkat. Hal ini tidak terlepas dari kondisi usaha ternak sapi yang memerlukan investasi biaya usaha ternak yang cukup besar sementara petani di daerah penelitian pada umumnya merupakan petani kecil sehingga kemampuan finansialnya terbatas. Usaha perikanan berupa ikan lele, nila, mas dan lain-lain memperlihatkan kecenderungan yang semakin meningkat. Demikian juga dengan usaha industri kecil dan industri menengah memperlihatkan kecenderungan yang semakin meningkat.

Kondisi perubahan lainnya terjadi pada area luas lahan perkebunan dan bangunan yang cenderung meningkat, luas lahan sawah semakin menurun dan 


\section{PEMETAAN SOSIAL (SOCIAL MAPPING) MASYARAKAT DALAM UPAYA MENDUKUNG PENGEMBANGAN USAHATANI POLIKULTUR PERKEBUNAN TERINTEGRASI (UTPPT)}

Rina Nuryati, Lies Sulistyowati, Iwan Setiawan, Trisna Insan Noor

pendapatan masyarakat memperlihatkan kecenderungan peningkatan yang cukup besar terutama pada periode ketiga pengamatan. Hal ini disebabkan karena aktivitas perekonomian masyarakat yang semakin meningkat sehingga mampu memberikan kontribusi yang cukup berarti bagi peningkatan pendapatannya.

Penyusunan kalender musim ditujukan untuk mengkaji kegiatankegiatan dan keadaan-keadaan yang terjadi secara berulang dalam kurun waktu tertentu (musim) dalam kehidupan masyarakat (Gambar 1). Kegiatan pengolahan lahan dilakukan pada musim hujan $(\mathrm{MH})$ yaitu sekitar bulan November sampai bulan Februari. Pada $\mathrm{MH}$ ini petani melakukan penanaman padi dan jagung, termasuk melakukan penanaman tanaman perkebunan seperti kakao, kopi dan kelapa apabila dirasakan masih memungkinkan pada lahan yang diusahakannya untuk ditanami tanaman perkebunan tersebut. Pada akhir musim hujan, petani menanami lahannya dengan tanaman jagung termasuk menanam tanaman tahunan (kelapa, pala dan kapulaga). Nono Sutrisno, et al., (2010) menyatakan bahwa sektor pertanian dalam menghadapi perubahan iklim, harus mengembangkan pertanian yang tahan terhadap perubahan iklim dan harus dibuat sebagai peluang untuk meningkatkan produktivitas. Pertanian lahan kering harus dapat memperkuat kemampuannya agar tetap berproduksi tinggi, dalam arti harus memiliki strategi adaptif yang tepat dan bahkan bisa memitigasi dampak negatif perubahan iklim. Usaha adaptasi pada pertanian lahan kering dilakukan dengan menerapkan sistem pengelolaan lahan dan air secara terpadu dan tepat supaya sistem pertanian dapat berproduksi secara berkelanjutan

\begin{tabular}{|c|c|c|c|c|c|c|c|c|c|c|c|c|c|c|}
\hline Kegiatan Bulan & 1 & 2 & 3 & 4 & 5 & 6 & 7 & 8 & 9 & 10 & 11 & 12 & \multicolumn{2}{|c|}{ Keterangan } \\
\hline Angin & $\nabla$ & $\nabla$ & & & & & & & & $\nabla$ & $\nabla$ & $\nabla$ & & \\
\hline Hujan & $\infty$ & 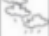 & द्टी & हो & يف & & & & & & 3 & sis & & \\
\hline Pengolahan Lahan & $r w$ & wwr & & & & $k \alpha$ & Lak & 2 & & & $w w$ & $w w$ & $\begin{array}{l}W \mathcal{W} \\
\mathcal{L K}: \text { : Padi }\end{array}$ & \\
\hline Tanam & $\begin{array}{l}\text { vww } \\
601\end{array}$ & wer & & & $\frac{1}{5}$ & $\begin{array}{l}k 25 \\
50 \\
50 \\
9\end{array}$ & $\begin{array}{l}154 \\
680 \\
800 \\
699\end{array}$ & $\begin{array}{l}5 \\
\vdots \\
\vdots \\
\vdots\end{array}$ & & & $\begin{array}{l}w v \\
e \theta 0 \\
00\end{array}$ & $\begin{array}{l}w w \\
020 \\
0000\end{array}$ & $\begin{array}{l}\text { Y Padi } \\
\text { K J Jagung } \\
\text { \& Kopi } \\
\text { Kakiao } \\
\text { \& Kelapa }\end{array}$ & $\begin{array}{l}\text { o Pisang } \\
\text { \& Pala } \\
\text { @ Kapulaga } \\
\text { o Lado } \\
\text { Kayu }\end{array}$ \\
\hline Panen & ii & iii & उ. & 花 & 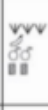 & y. & "if & iा & is & 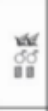 & 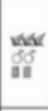 & $\begin{array}{l}\text { a } \\
68 \\
\text { ii }\end{array}$ & 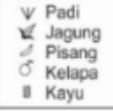 & \\
\hline Penyakit & $\infty$ & Dou & 마마 & a & 口 & & & & & & & & & \\
\hline Pacekilix & & & & & & 00 & 000 & $\infty 00$ & $\infty$ & 0 & & & & \\
\hline Kerja Luar Desa & & & & & & $\Delta \Delta$ & $\Delta \Delta \Delta$ & $\Delta \Delta \Delta$ & $\Delta \Delta$ & $\Delta$ & & & & \\
\hline $\begin{array}{l}\text { Pemasaran } \\
\text { hastanian } \\
\text { pertan }\end{array}$ & ii & ii & sio & if & 要 & $\frac{y}{y}$ & & ii & 采 & 㟧 & $\begin{array}{l}\text { nat } \\
\text { if } \\
\text { ii }\end{array}$ & $\begin{array}{l}\text { se } \\
\text { in }\end{array}$ & $\begin{array}{l}\text { Padi } \\
\text { S Jagung } \\
\text { ofelapa }\end{array}$ & $\begin{array}{l}\text { OPisang } \\
\text { i Kayu }\end{array}$ \\
\hline
\end{tabular}

Gambar 1 : Kalender Musim Desa Setiawaras 
Pengusahaan berbagai jenis tanaman dengan berbagai kondisi umur tanaman yang berbeda memberikan peluang kepada petani untuk meningkatkan aktivitas panen menjadi dapat dilakukan setiap bulan. Tanaman kelapa dan tanaman kayu-kayuan merupakan jenis tanaman yang dapat memberikan hasil panen setiap bulan, diikuti dengan aktivitas panen dari tanaman semusim (padi), tanaman pisang dan tanaman semusim lainnya (jagung). Keadaan ini menyebabkan petani dapat memasarkan hasil pertaniannya setiap bulan selama satu tahun, karena setiap bulan selalu ada tanaman yang dapat menghasilkan untuk dijual ke pengepul lokal maupun ke Bandar yang berada di luar desa.

memitigasi dampak negatif perubahan iklim. Usaha adaptasi pada pertanian lahan kering dilakukan dengan menerapkan sistem pengelolaan lahan dan air secara terpadu dan tepat supaya sistem pertanian dapat berproduksi secara berkelanjutan.

Pengusahaan berbagai jenis tanaman dengan berbagai kondisi umur tanaman yang berbeda memberikan peluang kepada petani untuk meningkatkan aktivitas panen menjadi dapat dilakukan setiap bulan. Tanaman kelapa dan tanaman kayu-kayuan merupakan jenis tanaman yang dapat memberikan hasil panen setiap bulan, diikuti dengan aktivitas panen dari tanaman semusim (padi), tanaman pisang dan tanaman semusim lainnya (jagung). Keadaan ini menyebabkan petani dapat memasarkan hasil pertaniannya setiap bulan selama satu tahun, karena setiap bulan selalu ada tanaman yang dapat menghasilkan untuk dijual ke pengepul lokal maupun ke Bandar yang berada di luar desa.

Dari hasil penyusunan kalender musim diketahui bahwa petani mengalami serangan penyakit pada tanaman yang dibudidayakannya pada bulan Januari yang terus meningkat selama bulan Februari dan Maret, pada bulan berikutnya yaitu bulan April dan Mei serangan hama penyakit mengalami penurunan. Hal tersebut berkaitan dengan adanya peningkatan curah hujan dari bulan Januari ke bulan Februari dan Maret yang menyebabkan kondisi lingkungan menjadi lebih lembab sehingga memicu perkembangan penyakit pada tanaman yang dibudidayakan. Pada bulan April dan Mei, curah hujan sudah jauh berkurang sehingga serangan penyakit tanaman juga menurun. Bulan Juni sampai bulan Oktober, curah hujan jauh berkurang dan terjadi musim paceklik. Pada kondisi ini petani banyak yang mencari aktivitas di luar usahatani dengan mencari pekerjaan ke luar desa.

Penelusuran desa/transek merupakan teknik pengamatan langsung terhadap lingkungan dan sumberdaya masyarakat dengan cara berjalan 


\section{PEMETAAN SOSIAL (SOCIAL MAPPING) MASYARAKAT DALAM UPAYA MENDUKUNG PENGEMBANGAN USAHATANI POLIKULTUR PERKEBUNAN TERINTEGRASI (UTPPT)}

Rina Nuryati, Lies Sulistyowati, Iwan Setiawan, Trisna Insan Noor

menelusuri wilayah desa atau dusun mengikuti suatu lintasan atau rute yang disepakati bersama masyarakat. Hasil pengamatan tersebut dituangkan dalam bagan atau irisan muka bumi (bentang alam berdasarkan tofografi) yang dituangkan pada kertas dan dilengkapi dengan hasil diskusi (Gambar 2).

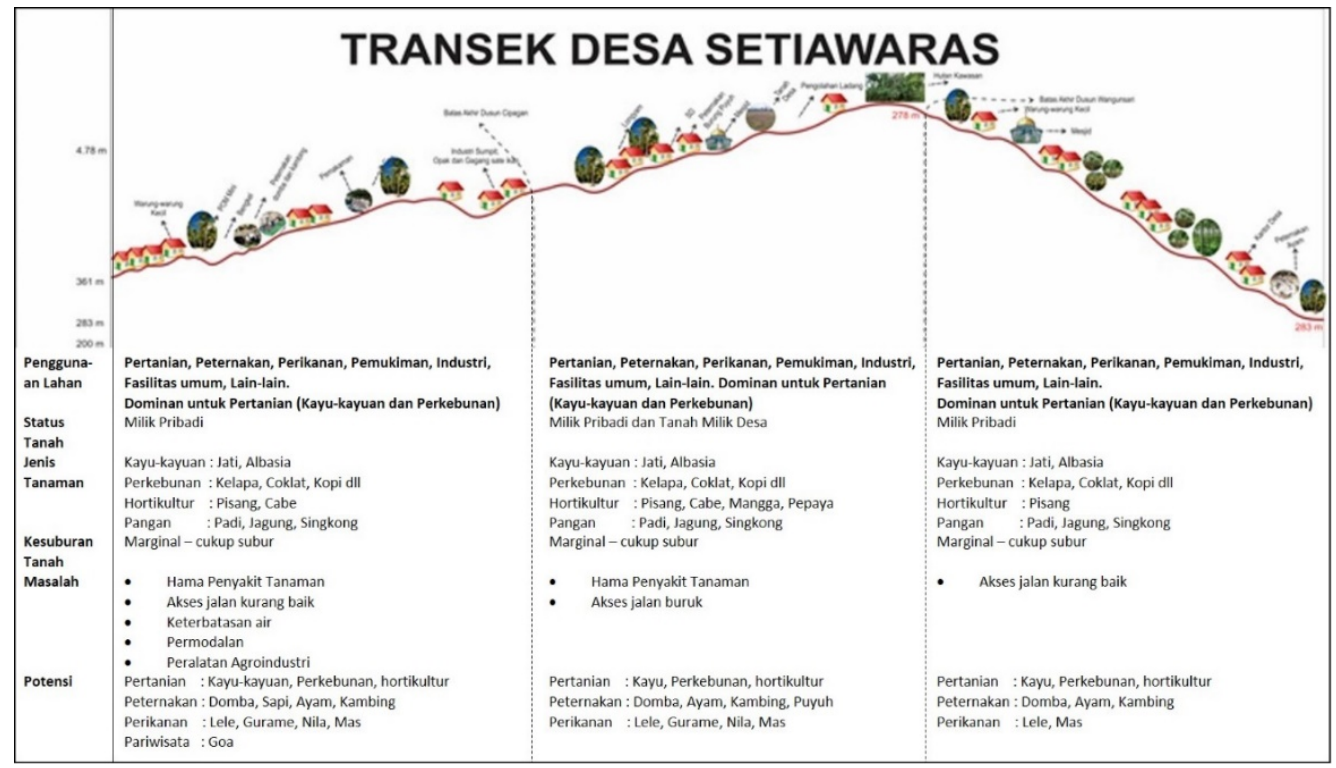

Gambar 2. Transek Desa Setiawaras

Rute atau lintasan yang dilalui selama penelusuran desa/transek dari mulai batas desa (sebelah kiri gambar) dijumpai penggunaan lahan untuk pemukiman, pertanian, peternakan, fasilitas umum, usaha perikanan, industri, termasuk penggunaan lainnya seperti bengkel, warung, pom mini, dll serta terdapat goa alam yang indah. Ke wilayah sebelah tengah dari Desa Setiawaras, penggunaan lahan lebih kurang sama akan tetapi pada wilayah bagian tengah ini terdapat areal hutan dan lahan milik desa, serta terdapat usaha ternak burung puyuh. Usaha perikanan di wilayah ini terkonsentrasi pada usaha ikan lele, sedangkan usaha industri pada aktivitas pembuatan lemari dan pengolahan lada hitam. Lebih lanjut penelusuran desa ke wilayah sebelah timur (kanan dari gambar), terdapat kantor desa Setiawaras yang merupakan pusat pemerintahan desa dan penggunaan lahan lainnya hampir

sama dengan kedua wilayah sebelumnya yaitu digunakan untuk pemukiman, pertanian, peternakan, perikanan, fasilitas umum, industri dan lainnya.

Status tanah mulai dari batas desa sebelah barat, tengah dan timur umumnya adalah lahan milik, kecuali dibagian tengah terdapat lahan milik desa. Kondisi tanah termasuk dalam kategori subur dan sangat subur, hal ini salah satunya disebabkan 


\section{JURNAL AGRISTAN}

Volume 2, Nomor 1, Mei 2020

karena kondisi usaha pertanian yang telah terintegrasi dengan usaha peternakan sehingga kebutuhan bahan organik tanah dapat terpenuhi yang menyebabkan kondisi tanah menjadi semakin baik.

Jenis tanaman yang diusahakan, pada bagian barat desa adalah tanaman pangan berupa padi, jagung dan singkong, tanaman hortikultura berupa tanaman pisang dan cabe, tanaman perkebunan berupa kelapa, kakao, lada, kapulaga, pala dan kopi, sedangkan tanaman kayukayuan berupa jati dan albasiah. Pada wilayah bagian tengah tanaman yang diusahakan hampir sama dengan di wilayah bagian barat hanya tanaman hortikultura diwilayah ini selain pisang dan cabe juga diusahakan tanaman manggis dan pepaya, tanaman perkebunan ada pengusahaan tanaman aren. Pada wilayah bagian timur, tanaman pangan yang diusahakan hanya padi, tanaman hortikultura hanya pisang dan tanaman perkebunan berupa cengkeh disamping tanaman perkebunan lainnya (kelapa, kapulaga, kopi, dan kakao/coklat).

Permasalahan yang ditemui pada wilayah bagian barat lebih kompleks dibandingkan dengan wilayah bagian tengah dan timur. Pada wilayah bagian barat, ditemui adanya masalah penyakit jamur pada kakao oleh cendawan Phytopthora palmivora, hama tupai pada tanaman kelapa, penyakit panas pada ternak kambing, domba dan sapi, keterbatasan modal dan mesin pada industri, kurangnya ketersediaan air dan akses jalan yang masih kurang baik. Pada wilayah bagian tengah, permasalahan yang ada adalah akses jalan yang buruk dan adanya serangan penyakit jamur pada kakao yang juga disebabkan oleh cendawan Phytopthora palmivora. Pada wilayah bagian timur, permasalahan yang ada adalah akses jalan yang kurang baik sehingga menghambat aktivitas warga sehari-hari.

Potensi yang dimiliki oleh Desa Setiawaras di bagian barat adalah pengembangan usaha pertanian baik tanaman pangan, perkebunan maupun hortikultura. Potensi pada usaha peternakan adalah mengusahakan ternak ayam, domba, kambing dan sapi, usaha perikanan pada pengembangan usaha ikan lele, bawal, gurame, nila dan ikan mas, serta pengembangan pariwisata berupa Goa. Pada wilayah bagian tengah, usaha pengembangan tanaman pangan sama seperti wilayah bagian barat yaitu pengembangan tanaman hortikultura, perkebunan dan hutan kawasan (area aenghijauan), potensi usaha peternakan adalah ternak ayam, domba dan kambing serta burung puyuh. Usaha perikanan berupa pengembangan ikan lele. Di wilayah sebelah timur, desa Setiawaras berpotensi untuk pengembangan tanaman pangan, perkebunan, dan hortikultura. Pengembangan usaha peternakan pada pengembangan ternak ayam, domba dan kambing, disertai dengan potensi pengembangan usaha perikanan berupa ikan mas dan ikan lele. Kajian hubungan 
Rina Nuryati, Lies Sulistyowati, Iwan Setiawan, Trisna Insan Noor

antara masyarakat dengan lembagalembaga yang terdapat di lingkungan Desa Setiawaras dituangkan dalam Diagram Venn (Gambar 3. ). Desa Setiawaras memiliki banyak lembaga kemasyarakatan yang saling berkaitan satu sama lain.

Kelembagaan pemerintahan desa merupakan

kelembagaan penyelenggaraan urusan pemerintahan oleh Pemerintah Desa dan BPD (Badan Permusyawaratan Desa) mengatur dan mengurus kepentingan masyarakat. BPD memiliki keterkaitan dengan (LPM) Lembaga Pemberdayaan Masyarakat yang keduanya berhubungan dengan kelembagaan Karang Taruna dan Kelompok Gotong Royong. Kelembagaan lainnya adalah keberadaan PKK (Pembinaan Kesejahteraan Keluarga) yang merupakan organisasi kemasyarakatan yang memberdayakan wanita untuk turut serta dalam pembangunan sehingga keberadaannya sangat terkait dengan keberadaan LPM.

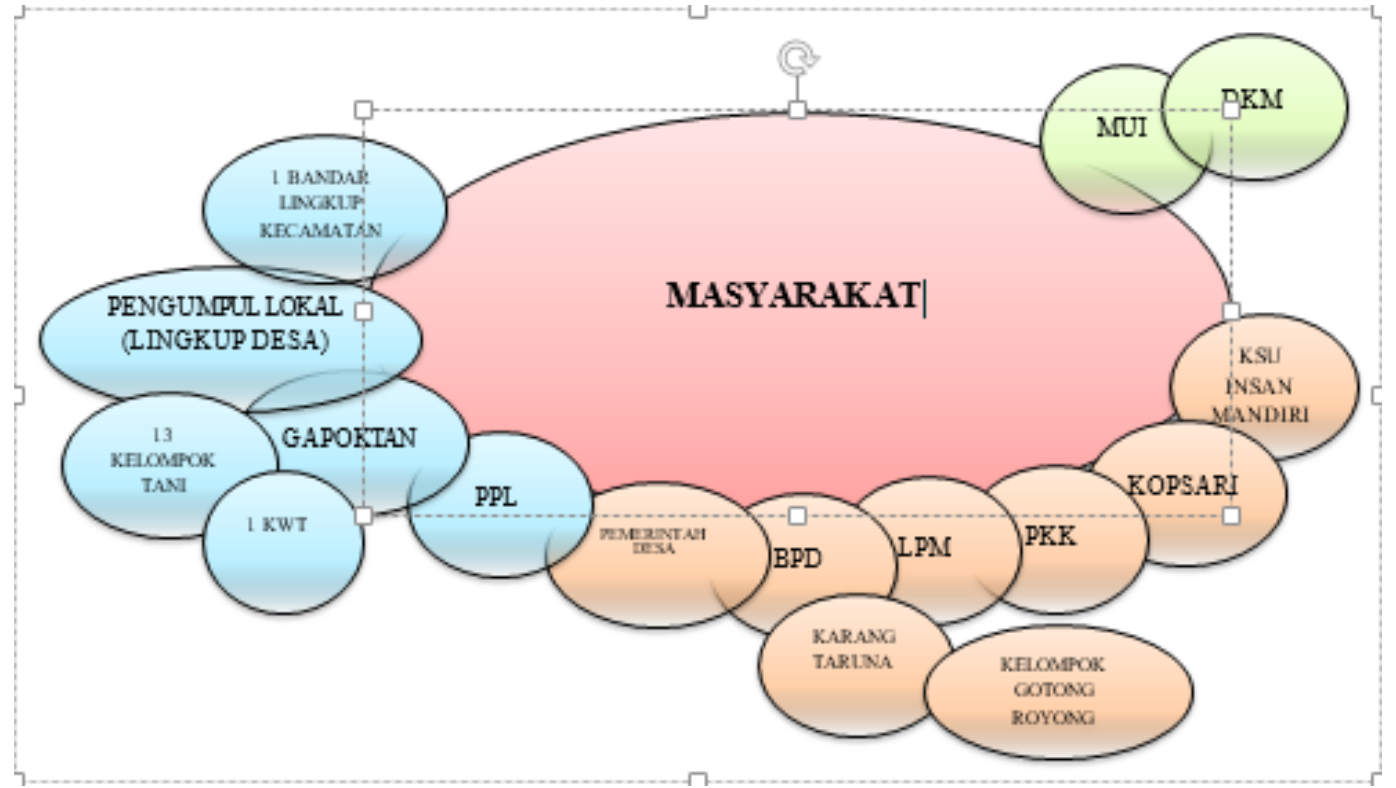

Gambar 3. Hubungan Masyarakat Desa Setiawaras dengan Lembaga-lembaga.

Dalam kaitannya dengan UTPPT yang menjadi bahasan dalam penelitian ini, Desa Setiawaras memiliki kelembagaan PPL (Penyuluh Pertanian Lapangan dan telah ada Gapoktan (Gabungan Kelompok Tani) yang membina 12 kelompok tani serta 1 KWT (Kelompok Tani Wanita). Dalam upaya memperlancar proses pemasaran hasil produk pertanian di Desa Setiawaras telah ada pengumpul local dan
Bandar di tingkat kecamatan. Kelembagaan di Desa Setiawaras juga dilengkapi dengan MUI (Majelis Ulama Indonesia) tingkat desa dan DKM (Dewan Kemakmuran Mesjid) yang merupakan organisasi yang dikelola oleh Jemaah muslim dalam melangsungkan aktivitas di masjid sehubungan dengan mayoritas penduduk Desa Setiawaras beragama Islam. 


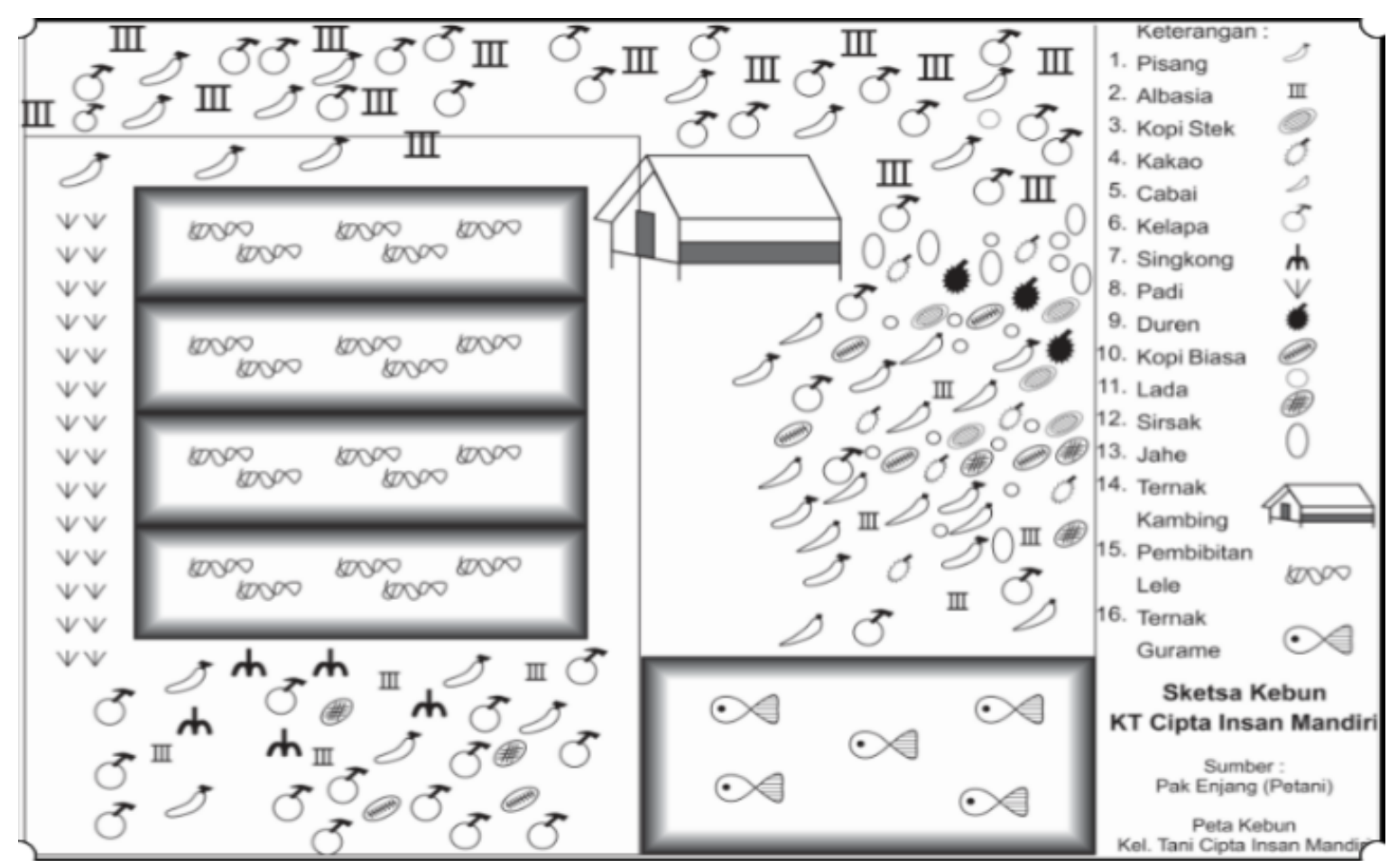

Gambar 4. : Sketsa Area Usaha Di Desa Setiawaras.

Sketsa area usaha merupakan peta pengkajian aspek pengelolaan usahatani polikultur yang dilakukan oleh petani di lokasi penelitian (Gambar 4.). Gambar 4 memperlihatkan bahwa petani mengusahakan lahannya dengan berbagai komoditas tanaman pertanian dan usaha ternak serta usaha perikanan. Tanaman kayu-kayuan yang diusahakan adalah albasiah, tanaman pangan berupa padi, singkong dan cabai, tanaman perkebunan berupa kopi, kakao, kelapa, dan lada, tanaman buah-buahan berupa pisang, duren dan sirsak, tanaman obatobatan berupa jahe. Ternak yang dipelihara oleh petani adalah kambing, sedangkan usaha perikanan petani mengusahakan ikan lele dan Gurame. Kokoye, et., al. (2013) dalam Joko
Mariyanto, dkk., (2016), pilihan penggunaan lahan dalam usahatani berkaitan erat dengan keputusan petani yang dipengaruhi oleh rasionalitas petani seperti menjamin ketahanan pangan rumah tangga, menjamin pendapatan tunai, meminimisasi risiko, memaksimisasi leisure terkait alokasi waktu, menjamin anggota keluarga dalam kondisi baik dan sejahtera serta meraih kelas social tertentu dalam komunitasnya.

Dari Gambar 4 juga dapat dilihat bahwa tanaman ditanam oleh petani dalam keadaan sangat tidak beraturan. Jarak antar barisan dan dalam barisan tidak tertata dengan baik, tanaman albasiah ada yang terdapat di sebelah belakang kebun, di bagian tengah dan bagian depan. Demikian juga dengan 
tanaman kelapa dan tanaman pisang, tanaman kakao, tanaman duren, tanaman lada, sirsak dan lain-lain campur baur ditanam ditengah kebun dan terlihat ditanam dengan tidak mengikuti teknis budidaya yang dianjurkan, ditempatkan dibelakang kandang dan diantara kolam ikan.Ketika suatu lahan pertanian ditanami dengan lebih dari satu jenis tanaman, maka pasti akan terjadi interaksi antara tanaman yang ditanam. Interaksi yang terjadi dapat saling menguntungkan (cooperation) dapat juga berlangsung saling menghambat (competition).

Menurut Eko Setiawan (2009), dalam pola tanam tumpangsari terdapat prinsip yang harus diperhatikan yaitu tanaman yang ditanam secara tumpangsari sebaiknya mempunyai umur atau periode pertumbuhan yang tidak sama, mempunyai perbedaan kebutuhan terhadap faktor lingkungan seperti air, kelembaban, cahaya dan unsur hara tanaman. Nina Mindawati, et., al. (2013) menjelaskan bahwa untuk memaksimalkan hasil pola Agroforestri/polikultur maka perlu pengaturan dan pemilihan jenis yang tepat agar selain hasil secara ekonomi meningkat juga lingkungan secara ekologi terjada keberlanjutannya.

Mata pencaharian penduduk Desa Setiawaras berdasarkan hasil kajian dari penelitian ini secara rinci dapat dilihat pada Tabel 3. Dari Tabel 3 terlihat bahwa penduduk desa Setiawaras bermatapencaharian di bidang pertanian sebagai petani dengan mengusahakan tanaman perkebunan, hortikultura, kayukayuan dan tanaman semusim. Selain itu, terdapat juga penduduk yang bermatapencaharian sebagai peternak dengan mengusahakan ternak domba, kambing, unggas dan sapi. Mata pencaharian lainnya yang ditekuni oleh penduduk yang ada di Desa Setiawaras adalah buruh tani/ternak. Di samping berusaha di bidang pertanian dan peternakan, penduduk Desa Setiawaras juga menekuni usaha pada industri kecil (penggilingan padi, pengolahan air nira menjadi gula aren serta pembuatan opak) dan industri menengah (pembuatan sumpit, gagang sair, pembibitan lele, dan pembuatan VCO).

Mata pencaharian sebagai petani merupakan mata pencaharian yang paling banyak dilakukan oleh penduduk di Desa Setiawaras yang mencapai 4.389 orang dengan status petani pemilik, diikuti dengan mata pencaharian sebagai peternak sebanyak 503 orang, sebagai buruh tani/ternak sebanyak 403 orang dan yang menekuni mata pencaharian di bidang industri kecil dan menengah sebanyak 53 orang 
JURNAL AGRISTAN

Volume 2, Nomor 1, Mei 2020

Tabel 3: Mata Pencaharian Penduduk Desa Setiawaras

\begin{tabular}{|c|c|c|c|c|}
\hline Jenis Usaha & Pemasaran & Bahan baku/hasil & $\begin{array}{l}\text { Bagaimana } \\
\text { mulai }\end{array}$ & Masalah \\
\hline \multicolumn{5}{|c|}{ Tanaman Perkebunan } \\
\hline $\begin{array}{l}\text { Coklat/ } \\
\text { Cacao }\end{array}$ & $\begin{array}{l}\text { Tidak sulit Rp 25.000/ } \\
\text { kg ke pengepul }\end{array}$ & $\begin{array}{l}\text { Mutu baik, bibit semai } \\
\text { sendiri }\end{array}$ & $\begin{array}{l}\text { Turun temurun }+ \\
\text { penyuluhan }\end{array}$ & $\begin{array}{l}\text { Busuk buah, penggerek batang } \\
\text { dan tupai }\end{array}$ \\
\hline Kelapa & Rp 1.400/butir & $\begin{array}{l}\text { Mutu baik, bibit semai/ } \\
\text { punya sendiri }\end{array}$ & Turun temurun & Pemupukan dan Tupai \\
\hline Kopi & $\begin{array}{l}\text { Pemasaran bagus, Rp } \\
20.000 / \mathrm{kg}\end{array}$ & Bibit beli & Penyuluhan & $\begin{array}{l}\text { Tadah hujan, hama kresek } \\
\text { penggerek batang }\end{array}$ \\
\hline Kapulaga & $\mathrm{Rp} \mathrm{40.000/kg}$ & $\begin{array}{l}\text { Bibit mudah dibeli, } \\
\text { mutu standar }\end{array}$ & Turun temurun & Perawatan intens \\
\hline Pala & $\mathrm{Rp} \mathrm{40.000/kg}$ & Bibit mudah dibeli & Turun temurun & - \\
\hline Lada & $\mathrm{Rp} \mathrm{70.000/kg}$ & $\begin{array}{l}\text { Bibit beli/ punya } \\
\text { sendiri, hasil menurun }\end{array}$ & Turun Temurun & Cuaca, Jamur \\
\hline \multicolumn{5}{|l|}{ Tanaman Hortikultura } \\
\hline Pisang & $\begin{array}{ll}\text { Harga } & \text { petani } \\
\text { Rp2.000/kg } & \end{array}$ & $\begin{array}{l}\text { Mutu baik, bibit punya } \\
\text { sendiri }\end{array}$ & Turun Temurun & Jamur \\
\hline \multicolumn{5}{|c|}{ Tanaman Kayu-kayuan } \\
\hline Albasiah & $\begin{array}{l}\text { Gampang dijual, } \quad \pm \\
\text { Rp500.000/ m3 }\end{array}$ & $\begin{array}{l}\text { Bibit beli, kualitas } \\
\text { standar }\end{array}$ & $\begin{array}{l}\text { Turun temurun + } \\
\text { penyuluhan }\end{array}$ & $\begin{array}{l}\text { Ulat daun, ulat batang, dan } \\
\text { bintil }\end{array}$ \\
\hline \multicolumn{5}{|l|}{ Tanaman semusim } \\
\hline Padi sawah & Rp500.000/kw GKP & $\begin{array}{l}\text { Bibit beli, hasil panen } \\
\text { baik }\end{array}$ & $\begin{array}{l}\text { Turun temurun }+ \\
\text { penyuluhan }\end{array}$ & Penyakit, hama, pola tanam \\
\hline \multicolumn{5}{|c|}{ Total pemilik : 4.389 orang } \\
\hline \multicolumn{5}{|c|}{ Ternak } \\
\hline Domba & $\begin{array}{l}\text { Dijual bila perlu } \\
\text { Rp40.000/ kg hidup }\end{array}$ & Beli/ tukar tambah & $\begin{array}{l}\text { Turun temurun }+ \\
\text { penyuluhan }\end{array}$ & $\begin{array}{lll}\text { Kesehatan } & \text { ternak } & \text { tidak } \\
\text { diperhatikan } & & \end{array}$ \\
\hline Kambing & $\begin{array}{l}\text { Dijual bila perlu } \\
\text { Rp40.000/ kg }\end{array}$ & Beli/ tukar tambah & $\begin{array}{l}\text { Turun temurun }+ \\
\text { penyuluhan }\end{array}$ & $\begin{array}{lll}\begin{array}{l}\text { Kesehatan } \\
\text { diperhatikan }\end{array} & \text { ternak } & \text { tidak } \\
\end{array}$ \\
\hline \multicolumn{5}{|l|}{ Unggas } \\
\hline Sapi & $\begin{array}{l}\text { Sapi umur sebelas } \\
\text { bulan Rp } 11 \mathrm{jt}\end{array}$ & Beli & Hibah & $\begin{array}{ll}\text { Kurang } & \text { pengetahuan } \\
\text { perawatan } & \\
\end{array}$ \\
\hline \multicolumn{5}{|c|}{ Total peternak : 503 orang } \\
\hline \multicolumn{5}{|c|}{ Total Buruh tani/ternak : 403 orang } \\
\hline \multicolumn{5}{|c|}{ Industri kecil } \\
\hline Penggiling-an Padi & $\begin{array}{l}\text { Jumlah konsumen } \\
\text { cukup }\end{array}$ & & Turun temurun & \\
\hline Gula aren & $\begin{array}{ll}\text { Konsumen } & \text { banyak } \\
\text { Rp15.000/ kg } & \end{array}$ & Hasil sedikit & Turun temurun & Pohon terus ditebang \\
\hline Opak & $\begin{array}{l}\text { Konsumen terbuka, } \\
\text { warung Rp500/butir, } \\
\text { hajatan Rp600/ butir }\end{array}$ & $\begin{array}{l}\text { Produksi masih sedikit } \\
\text { dan tidak memenuhi } \\
\text { pasar }\end{array}$ & Ide sendiri & Alat sederhana \\
\hline Warung & Konsumen sekitar & Beli dipasar & $\begin{array}{l}\text { Keinginan } \\
\text { sendiri }\end{array}$ & Jarak antar rumah berjauhan \\
\hline \multicolumn{5}{|l|}{ Industri menengah } \\
\hline Sumpit & Konsumen terbuka & $\begin{array}{l}\text { Bamboo Rp800 - Rp } \\
1.400 / m\end{array}$ & Ide sendiri & Bahan baku kadang sulit dicari \\
\hline Gagang sair & $\begin{array}{l}\text { Konsumen terbuka Rp } \\
7.000 \text { - Rp } 15.000\end{array}$ & $\begin{array}{l}\text { Kayu-kayuan jenis } \\
\text { keras }\end{array}$ & Ide sendiri & $\begin{array}{l}\text { Alat mesin sulit dicari harus } \\
\text { dirakit }\end{array}$ \\
\hline Pembibit-an lele & Konsumen terbuka & Bibit lele sendiri & Ide sendiri & $\begin{array}{l}\text { Lokasi dan teknik budidaya } \\
\text { perlu ketelitian }\end{array}$ \\
\hline VCO & Konsumen terbuka & $\begin{array}{l}\text { Hasil banyak pasar } \\
\text { kurang }\end{array}$ & $\begin{array}{l}\text { Ide melihat } \\
\text { limbah organic } \\
\text { menumpuk }\end{array}$ & $\begin{array}{l}\text { Pasar sulit kurang dukungan } \\
\text { pemerintah }\end{array}$ \\
\hline
\end{tabular}

Sumber : Pak Enjang (Ketua Kelompok Tani Cipigan Insan Mandiri) 
Usahatani tanaman perkebunan, hortikultura, kayu-kayuan dan tanaman semusim merupakan usahatani yang telah dilakukan oleh petani di desa Setiawaras secara turun temurun. Benih atau bibit tanaman yang digunakan ada yang berasal dari hasil pembibitan sendiri maupun membeli dari penjual benih/bibit. Pemasaran hasil produksi tidak ada kendala berarti, permasalahan timbul pada proses produksi yaitu adanya serangan hama dan penyakit, diantaranya adalah adanya serangan busuk buah dan penggerek batang serta tupai pada tanaman kakao, pada budidaya kopi terjadi serangan hama kresek dan penggerek batang, pada tanaman albasiah terjadi serangan ulat daun, ulat batang dan bintil, dan seterusnya.

Usaha ternak domba dan kambing seperti halnya usahatani pada umumnya juga merupakan usaha yang telah berlangsung secara turun temurun kecuali usaha ternak sapi yang merupakan usaha yang dilakukan karena memperoleh bantuan dari pemerintah berupa hibah. Kendala yang dihadapi pada usaha ternak sapi adalah kurangnya pengetahuan peternak tentang teknis perawatan atau pemeliharaan ternak sapi.

Mata pencaharian pada industri baik industri kecil maupun menengah dilakukan karena merupakan usaha turun temurun (penggilingan padi dan gula aren), ada pula yang ditekuni masyarakat karena keinginan sendiri/ide sendiri. Berbagai permasalahan dihadapi masyarakat dalam melaksanakan usaha pada bidang industri diantaranya adalah pada industri gula aren, pohon aren sebagai penghasil bahan baku terus ditebang. Permasalahan pada pengrajin opak adalah alat yang digunakan masih sederhana, sementara itu pada industri skala menengah, permasalahan yang terjadi adalah bahan baku yang terkadang sulit diperoleh pada pembuatan sumpit, pada pembibitan lele petani menghadapi permasalahan lokasi dan teknik budidaya memerlukan ketelitian, serta pada industri VCO sulitnya memasarkan produk yang dihasilkan.

Dalam upaya mengetahui sistemsistem yang ada pada masyarakat desa Setiawaras dilakukan teknik pemetaan. Teknik pemetaan ini berupa sistem yang digambarkan dalam bentuk bagan yang memperlihatkan bagian-bagian dalam sistem (input dan output). Input adalah sumberdaya yang membuat sistem berjalan dan output adalah manfaat atau hasil yang diperoleh (Gambar 5.). Sistem pengelolaan usahatani tanaman pangan berupa padi sawah dan pemasarannya, dilakukan petani di Desa Setiawaras dengan menggunakan sumber bahan baku yang sebagian diperoleh dari subsidi. Produk yang dihasilkan berupa 
gabah kering yang sebagian besar (90 persen) digunakan untuk memenuhi memenuhi kebutuhan keluarga dan sisanya (10 persen) dijual kepada pengepul yang ada di dalam desa. Oleh pengepul, gabah tersebut dikeringkan dan masuk pada industri pengolahan padi menjadi beras selanjutnya dijual pada Bandar yang juga masih berada di dalam desa Setiawaras. Beras tersebut selanjutnya dipasarkan di pasar local dengan konsumen yang berasal dari dalam desa.

Sistem pengelolaan tanaman kayu-kayuan berupa tanaman albasiah dan pemasarannya, dilakukan dengan menggunakan bibit yang berasal dari penjual bibit yang secara langsung mendatangi konsumen yang membutuhkan. Produk yang dihasilkan berupa kayu gelondongan yang selanjutnya dijual pada Bandar untuk disampaikan pada konsumen yang membutuhkan. Sistem pengelolaan ternak berupa kambing dan pemasarannya, dilakukan dengan menggunakan anakan yang berasal dari hasil usaha pembibitan sendiri. Hasil produksi berupa kambing hasil pembesaran dijual kepada pengepul yang ada dalam desa kemudian dijual ke Bandar untuk seterusnya dijual ke pasar hingga sampai ke konsumen.

Sistem pengelolaan tanaman kakao dan pemasarannya, dilakukan dengan menggunakan benih yang berasal dari hasil pembenihan sendiri atau menggunakan bibit kakao yang berasal dari penjual bibit keliling. Hasil produksi berupa buah kakao yang selanjutnya dikeringkan menjadi biji kering sebelum dijual ke Bandar yang berada di Kabupaten Tasikmalaya. Biji kakao kering oleh Bandar kemudian dijual ke pasar yang berlokasi di kabupaten Tasikmalaya untuk dijual kembali pada konsumen yang ada di lokasi yang sama. Desa Setiawaras merupakan desa yang telah berhasil mengembangkan industri pengolahan bambu menjadi sumpit. Bahan baku industri sumpit dipenuhi dari pengepul local, produk yang dihasilkan berupa batang bambu yang telah diolah dan disebut dengan istilah sumpit dan dipasarkan kepada Bandar dari luar kecamatan untuk selanjutnya dijual ke pasar dan disampaikan pada konsumen yang juga berlokasi di luar kecamatan. 


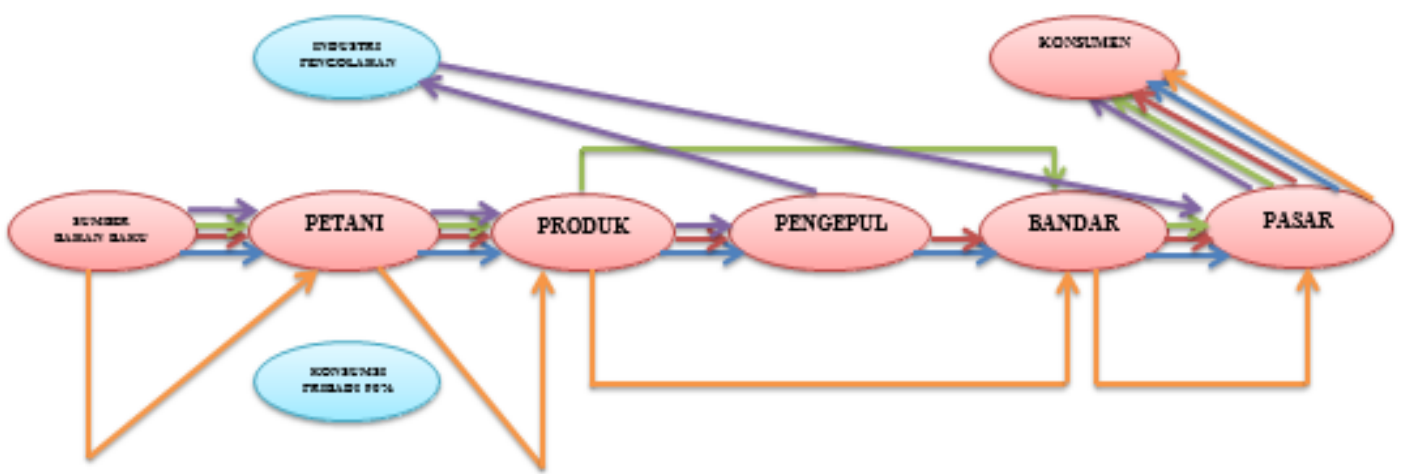

\begin{tabular}{|c|c|c|c|c|c|c|c|c|}
\hline so. & xosooditss & 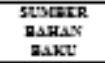 & mTtaxt & grodtk & 7ENGE7th & $\operatorname{maXDAR}$ & $7 \Delta s \Delta z$ & woxstaurx \\
\hline 1 & $\Rightarrow \mathrm{ADI}$ & $\begin{array}{l}\text { TrRDARAT } \\
\text { stustmi }\end{array}$ & $\begin{array}{l}7 \text { ADI } \\
\text { SAWAS }\end{array}$ & $\begin{array}{l}\text { CAAMH } \\
\text { XERING } \\
\end{array}$ & $\begin{array}{l}\text { DALAM } \\
\text { DESA }\end{array}$ & DAL_AM AIX A & 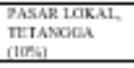 & 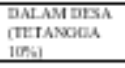 \\
\hline 2 & A.nusesh & $\begin{array}{l}\text { MEMuEnt.1 } \\
\text { sExDas }\end{array}$ & ALLAssu & \begin{tabular}{|l|} 
RAYTI \\
CELONDO \\
NEAX \\
\end{tabular} & - & & & \\
\hline 3 & 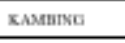 & $\begin{array}{l}\text { TURIN } \\
\text { TESERTIN } \\
\end{array}$ & 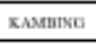 & E.AMars & $\begin{array}{l}\text { DALAM } \\
\text { DESA }\end{array}$ & & & \\
\hline 4 & XAKAD & 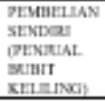 & XAKAO & 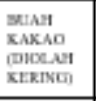 & - & $\begin{array}{l}\text { XABUIRATEN } \\
\text { TASIKMALAYA }\end{array}$ & $\begin{array}{l}\text { XABLRATIN } \\
\text { TASIKMALAYA }\end{array}$ & $\begin{array}{l}\text { XАBUIRATEN } \\
\text { TASIKMALAYA }\end{array}$ \\
\hline 5 & $\begin{array}{l}\text { INPEestRI } \\
\text { StMert }\end{array}$ & 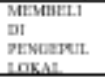 & susar & 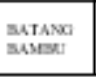 & $\begin{array}{l}\text { DALAMM } \\
\text { DESA }\end{array}$ & $\begin{array}{l}\operatorname{maR} \\
\text { XECAMUTAN }\end{array}$ & $\begin{array}{l}\text { EAR } \\
\text { XBCAMUTAN }\end{array}$ & $\begin{array}{l}\text { LAR } \\
\text { XECAMUTAN }\end{array}$ \\
\hline
\end{tabular}
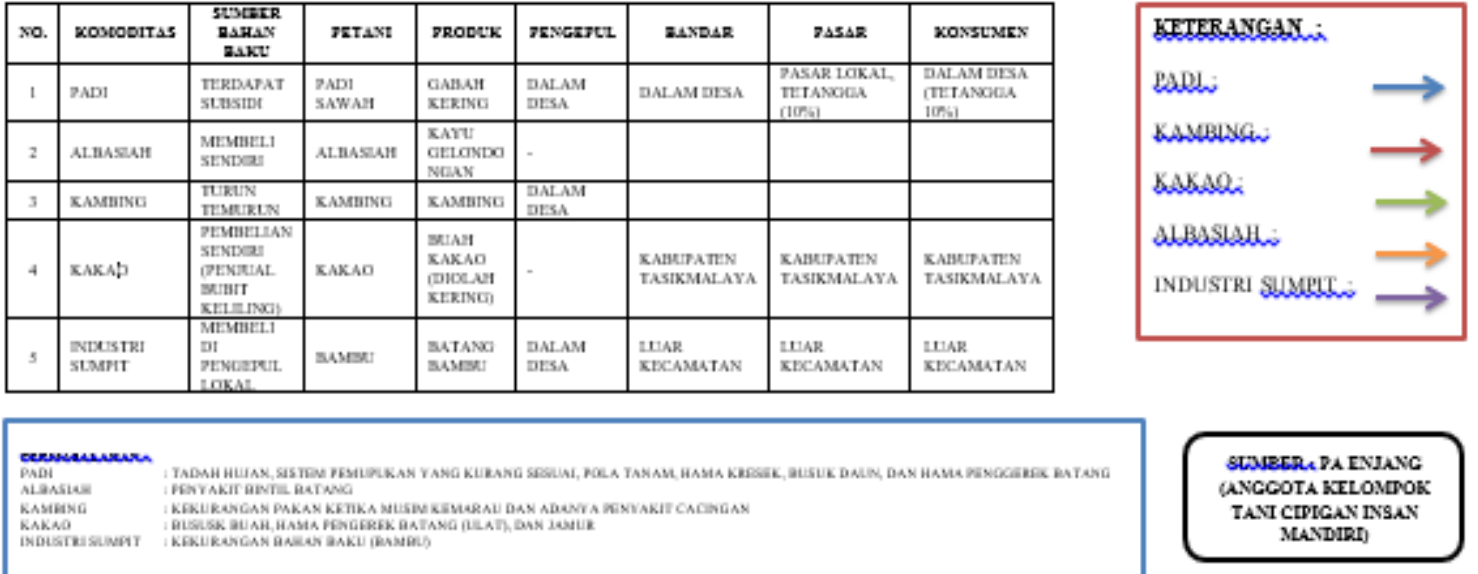

SLNEERT DA ENIANC ANGCOTA KELONDOK TANI CIPICAN INSA: MANDIRI)

\section{Gambar 5. Bagan Alur Produksi dan Pemasaran Desa Setiawaras Kecamatan Cibalong.}

\section{KESIMPULAN}

Usahatani tanaman polikultur telah lama ditekuni petani dan telah menjadi matapencaharian pokok bagi sebagian besar penduduk. Kondisi tanah yang termasuk pada kategori subur dan sangat subur ditunjang dengan keberadaan berbagai kelembagaan baik formal maupun non formal dan alur sistem in put dan out put serta pemasaran produk hasil pertanian yang lancar sangat mendukung pengembangan usahatani polikultur. Meskipun demikian masih terdapat beberapa hal yang memerlukan penanganan lebih lanjut diantaranya adalah kondisi iklim yang tidak menentu berpengaruh terhadap ketersediaan air yang jauh berkurang pada MK dan berlebih pada $\mathrm{MH}$ serta serangan hama dan penyakit yang meningkat pada $\mathrm{MH}$. Selain itu, kondisi kebun yang belum terpelihara dengan baik sehingga produktivitas tanaman pada umumnya rendah, peran kelembagaan yang belum optimal dan masih banyak produk yang dijual dalam bentuk produk mentah sehingga harga produk murah.

\section{SARAN}

Perlu dilakukan pengelolaan air yang optimal sehingga tidak berlebih pada saat $\mathrm{MH}$ dan tidak kekurangan pada 
saat MK melalui pengelolaan UTPPT yang maksimal disertai dengan pengembangan industry pengolahan hasil pertanian agar produktivitas usahatani naik, pendapatan petani meningkat, nilai produk bertambah dan kesejahteraan petani dapat terwujud.

\section{DAFTAR PUSTAKA}

Abdurahman, Ismail, Dan Sutono. 1997. Dukungan Penelitian Terhadap Pengembangan Pertanian lahan Kering. Prosiding Lokakarya nasional Pertanian Lahan Kering Di Kawasan Timur Indonesia. Malang 10-12 Oktober 1996. Dewan Pengembangan Kawasan Timur Indonesia.

Bahruddin, Krisdyatmiko, Danang Arif Darmawan, dan Soetomo. 2013. Indikator proper Hijau Aspek Pengembangan Masyarakat (Community Development) Peraturan Menteri Lingkungan Hidup Republik Indonesia Nomor 06 Tahun 2013 Tentang Proper. Deputi Pengendalian dan Pencemaran Kementrian Lingkungan Hidup RI. Jurusan Pembangunan Sosial dan Kesejahteraan Fakultas Sosial dan IImu Politik Universitas Gadjah Mada.

Data Profil Wilayah Kecamatan Cibalong Bappeda Kabupaten Tasikmalaya Tahun 2016.

Eko Setiawan. 2009. Kearifan Lokal Pola Tanam Tumpangsari di Jawa Timur. Agrivigor Volume 2 No.2. Fakultas Pertanian Universitas Trunojoyo. Bangkalan Madura.

Joko Mariyanto, Rini Dwiastuti dan Nuhfil Hanani. 2016. Model Ekonomi Rumah Tangga Pertanian Lahan Kering di Kabupaten Karanganyar Propinsi Jawa Tengah. Habitat,
Volume 26, No. 2, Agustus 2015, Hal 108-118. ISSN : 0853-5167.

Liyama, M., S. Kaitibie, P. Kariuki and Y. Morimoto. 2007. The status of croplivestock system and evolution toward integration. Annals of Arid Zone 46 (3\&4): 1-23.

Mochtar M. 2012. Prospek Pemberian Alkohol Alifatis untuk Peningkatan Produksi Vanilli (Tinjauan Secara Fisiologis Tanaman). Primordia. Vol $8: 2$

Netting, F. Ellen, Peter M. Kettner dan Steven L. McMurtry, 1993. Social Work Macro Practice, New York. Longman.

Nina Mindawati, A. Syaffari Kosasih, Sofwan Bustomi, Sitompul SM, dan Sutyono Yudo Tyasmoro. 2013. Pola Agroforestri Untuk Meningkatkan Fungsi Ekologi Dan Agroekonomi Hutan Rakyat. Pusat Litbang Peningkatan Produktivitas Hutan Fakultas Pertanian Universitas Brawijaya. Prosiding Seminar Nasional Agroforestri 2013.

Nono Sutrisno. Muhrizal Sarwani, dan Effendi Pasandaran. 2010. Memperkuat Kemampuan Pertanian lahan Kering Dalam Menghadapi Perubahan Iklim.

Notenbaert, A., M. Herrero, H. D. Groote, L. You, E. Gonzalez-Estrada, and M. Blummel. 2013. Identifying recommendation domains for targetting dual-purpose maizebased interventions in croplivestock systems in East Africa. Land Use Policy 30:834-846.

Pambudi handoyo dan Arief Sudrajat. 2016. Pemetaan Sosial untuk Perencanaan Pemberdayaan Masayarakat Desa Kemantren, Lamongan dalam Prosiding Seminar Nasional Mengawal Pelaksanaan SDGs (Sustainable Development Goals). ISBN : 978979-028-859-1. Prodi Sosiologi 
PEMETAAN SOSIAL (SOCIAL MAPPING) MASYARAKAT DALAM UPAYA MENDUKUNG

PENGEMBANGAN USAHATANI POLIKULTUR PERKEBUNAN TERINTEGRASI (UTPPT)

Rina Nuryati, Lies Sulistyowati, Iwan Setiawan, Trisna Insan Noor

Jurusan IImu Sosial Fakultas IImu

Sosial dan Hukum. UNESA

University Press. Surabaya.

Pasandaran, E., Djajanegara, A., Kariyasa K., dan Kasryno F. 2005.

Kerangka Konseptual Integrasi

Tanaman-ternak di Indonesia.

Integrasi Tanaman-Ternak di

Indonesia, Badan Litbang

Pertanian, Departemen Pertanian.

Jakarta. 